\title{
APPENDIX IV
}

\section{THE DEGRANULATION TEST}

\author{
P. A. LEFEVRE
}

ONE of the first morphological lesions seen in the secretory organs of the animals treated with carcinogens is the degranulation of rough endoplasmic reticulum and the resultant increase in smooth endoplasmic reticulum. Degranulation has been caused by many carcinogens with structures as diverse as the azo dyes (Porter and Bruni, 1959; Svoboda and Higginson, 1968; Ketterer et al., 1967), dimethyl- and diethyl-nitrosamine, ethionine and aflatoxin $\mathrm{B}_{1}$ (Svoboda and Higginson, 1968) and 2-acetylaminofluorene (Flaks, 1970). Williams and Rabin (1969) found that the degranulation effect could be reproduced in vitro using an isolated liver rough endoplasmic reticulum preparation incubated with aflatoxin $B_{1}$.

The liver provided a good model for the study of carcinogen-induced degranulation for 2 reasons: firstly it was a rich source of rough endoplasmic reticulum and secondly it has the metabolic capacity required to generate active forms of carcinogen from precursors. The main difficulties experienced are in the methods employed to monitor ribosome loss. Williams and Rabin (1971) assayed the rearrangease activity of membranes before and after treatment with carcinogen. As the ribosomes were removed, the enzyme was exposed and its activity estimated. However, the enzyme assay is a multistage operation, depending on several parameters. Rearrangease catalyses the correct distribution of the disulphide bonds which maintain the tertiary structure of proteins. Therefore, a substrate with its disulphide bridges in the incorrect positions must be used for the assay. In practice (Williams and Rabin, 1971), ribonuclease with randomly reoxidized disulphide bridges was used.

A direct method of monitoring ribosome loss is by estimating RNA/protein ratios of membranes. This ratio is decreased in degranulated membranes due to the loss of RNA with the ribosomes. However, accurate RNA determinations are essential, as the changes in RNA content are small. The sensitivity of the RNA assay cannot easily be improved and the analysis takes a considerable length of time. Because of the inherent difficulties with the rearrangease assay, the use of membranes containing radiolabelled RNA was developed (Purchase and Lefevre, 1975).

\section{MATERIALS AND METHODS}

\section{General}

Buffers were made up as follows.-(a) $0.25 \mathrm{M}$ sucrose (Aristar, B.D.H.) in $50 \mathrm{~mm}$ Trizma base (reagent grade, Sigma chemicals) $25 \mathrm{~mm} \mathrm{KCl}$ and $5 \mathrm{~mm} \mathrm{mg} \mathrm{Cl}_{2}(0 \cdot 25 \mathrm{M}$ STKM) and titrated to $\mathrm{pH} 7.5$ with $\mathrm{HCl}$ (b) $1.35 \mathrm{M}$ sucrose, with ion concentration and $\mathrm{pH}$ as above (1.35M STKM). (c) $2 \cdot 0 \mathrm{M}$ sucrose, with ion concentration and $\mathrm{pH}$ as above $(2 \cdot 0 \mathrm{M}$ STKM).

Co-factor solution contained in $0.5 \mathrm{ml}$.NADP monosodium salt (Sigma grade, Sigma chemicals) $1 \cdot 3 \mu \mathrm{mol}$; glucose-6-phosphate monosodium (Sigma) $20 \mu \mathrm{mol}$; nicotinamide (Sigma) $100 \mu \mathrm{mol}$.

The cofactor solution was made in bulk in $0 \cdot 25 \mathrm{M}$ STKM and stored frozen at $-20^{\circ} \mathrm{C}$ in $10 \mathrm{ml}$ portions.

\section{Membrane preparation}

Six male rats (170-200 g) of the Wistarderived Alderley Park strain were starved for $24 \mathrm{~h}$ to deplete pyrmidine precursors. Each animal was then injected i.p. with $0.5 \mathrm{ml}$ of a solution of $\left[6-{ }^{14} \mathrm{C}\right]$ orotic aid monohydrate in distilled water $(50 \mu \mathrm{Ci}$, $146 \mu \mathrm{g}$ per rat, (The Radiochemical Centre, Amersham, Bucks). The dosed animals were fed to stimulate uptake of label and killed by cervical dislocation $17 \mathrm{~h}$ after injection. This interval is required for effective labelling of ribosomal RNA, which has a half-life of 
$\sim 5$ days (Loeb et al., 1965). The livers were removed from the animals, washed in ice-cold $0 \cdot 25 \mathrm{M}$ STKM, cut into small pieces and homogenized in ice-cold $0 \cdot 25 \mathrm{M}$ STKM $(25 \%$ w/v homogenate using 8 passes of a PotterElvehjem homogenizer) running at 1070 $\mathrm{rev} / \mathrm{min})$. The homogenate was centrifuged at $19,000 \mathrm{~g}$ in an MSE 18 refrigerated centrifuge for $10 \mathrm{~min}$ at $4^{\circ} \mathrm{C}$. This supernatant was layered over a sucrose discontinuous density gradient of $8 \mathrm{ml} 2 \cdot 0 \mathrm{M}$ STKM and $12 \mathrm{ml} 1 \cdot 35 \mathrm{M}$ STKM. Centrifugation at $105,000 \mathrm{~g}$ for $4.5 \mathrm{~h}$ at $4^{\circ} \mathrm{C}$ in an MSE Superspeed 50 centrifuge produced a separation of the smooth and rough endoplasmic reticulum fraction (SER, RER) at the interfaces. The membranes were separately removed by aspiration, diluted $3 \times$ with $0 \cdot 25 \mathrm{M}$ STKM and pelleted by centrifugation at $105,000 \mathrm{~g}$ (max.) for $1.5 \mathrm{~h}$ at $4^{\circ} \mathrm{C}$. The membranes were stored overnight as frozen pellets at $-70^{\circ} \mathrm{C}$. The SER and RER were resuspended by adding $8 \mathrm{ml}$ of warmed $\left(45^{\circ} \mathrm{C}\right)$ $0 \cdot 25 \mathrm{M}$ STKM to each pellet, using the same homogenization techniques used for membrane preparation. Warmed buffer was used in order to thaw the membranes rapidly and so prevent damage to both membrane structure and microsomal activity (Fleischer and Kervina, 1974).

One-ml portions RER containing $\sim 5 \mathrm{mg}$ protein were rapidly frozen with $\mathrm{CO}_{2}$ /acetone, in $25 \mathrm{ml}$ conical tubes and stored at $-70^{\circ} \mathrm{C}$. At this temperature the loss of microsomal enzyme activity is kept to a minimum (Borton et al., 1974).

\section{Degranulation scheme}

RER portions were rapidly thawed. Samples were made up to $3 \mathrm{ml}$ each by the addition of $0 \cdot 25 \mathrm{M}$ STKM alone, or the same buffer containing the components of the generating system. The test compound, usually dissolved in dimethyl sulphoxide (DMSO) was added to the RER at $25^{\circ} \mathrm{C}$. Control samples contained the requisite volume of solvent alone. In the case of compounds insoluble in DMSO, alternative solvents were used, such as water, DMSO : acetone $(5: 3 \mathrm{v} / \mathrm{v})$ or DMSO: ethanol $(5: 3)$. Controls were always incubated in the presence of the relevant solvent mixture. DMSO was always used, even in the case of water-soluble compounds, as it appeared to have a stabilizing effect on the membranes.

The reaction was started with either enough NADPH (dissolved in $0 \cdot 25 \mathrm{~m}$ STKM, $\mathrm{pH} 7 \cdot 5$ ) to give a final concentration of $0.5 \mathrm{~mm}$ or 2.5 units of glucose-6-phosphate dehydrogenase (G6PD, Type XV Sigma) in the case of incubations using a generating system. Samples were incubated at $25^{\circ} \mathrm{C}$ shaking at $120 \mathrm{cycles} / \mathrm{min}$ in a water bath. After $1 \mathrm{~h}$ incubation, either NADPH was added to bring the concentration to $1.0 \mathrm{~mm}$ or a further 2.5 units of G6PD. The use of spectral measurements at $340 \mathrm{~nm}$, using an SP800 spectrophotometer (Unicam) showed that NADPH was still being produced at maximum levels after $2 \mathrm{~h}$ from this generating system.

At the end of $2 \mathrm{~h}$ total incubation, the samples were made more viscous by the addition of $2 \cdot 0 \mathrm{M}$ STKM to a molarity of $0 \cdot 7 \mathrm{M}$ with respect to sucrose, in order to slow down membrane sedimentation and so prevent physical trapping of polysomes in the membranes. The samples were then layered over a discontinuous density gradient of $3.5 \mathrm{ml} 2 \cdot 0 \mathrm{M}$ STKM and $1.0 \mathrm{ml} 1.35 \mathrm{M}$ STKM and centrifuged at $100,000 \mathrm{~g}$ for $8 \mathrm{~h}$ at $4^{\circ} \mathrm{C}$. The membranes, present in the 1.35M STKM layer, were removed by aspiration, diluted with $0 \cdot 25 \mathrm{M}$ STKM and pelleted by centrifugation at $200,000 \mathrm{~g}(\max )$ for $1.5 \mathrm{~h}$. Membrane pellets were stored at $-20^{\circ} \mathrm{C}$ until analysis.

Membranes were resuspended in water $(10 \mathrm{ml})$ by ultrasonication, using an exponential probe at $10 \mu \mathrm{m}$ amplitude fitted to an MSE 150-watt ultrasonic disintegrator. Aliquots of $0.2 \mathrm{ml}$ were removed for the estimation of radioactivity. The radioactivity present in the original membranes and extracts was measured by counting in Instagel (Packard) using an Intertechnique LS30 scintillation counter. Efficiency of counting, as determined by the use of an internal standard, was $>90 \%$. Portions were also analysed for protein, using the Lowry manual (Lowry et $a l ., 1951$ ) or automated (Gaunce and D'Iorio, 1970) method. The protein and radioactvity of RER and SER samples were analysed in the same way.

Ten aliquots of RER were incubated simultaneously. Controls and tests were always carried out in duplicate. The specific activity of membranes (radioactivity/mg membrane protein) was considered to be an accurate estimate of $\mathrm{RNA} /$ protein ratio of the membrane. A reduction in $\mathrm{RNA} /$ protein ratio was taken as an index of degranulation. 
The specific activity (or RNA/protein ratio) of the SER establishes the lowest value that can be reached by totally degranulated RER. The difference between the specific activity of SER and RER represents the theoretical maximum degranulation. Therefore, the difference in values between test and control incubations can be expressed as a percentage degranulation caused by a particular compound.

The criterion for a valid experiment was that the duplicate samples were in close agreement. Degranulation of $5 \%$ was considered positive. The amount of compound used for each test is shown in the relevant tables. Three compounds, the polycyclic hydrocarbon 3,4 benzpyrene and 2 arylamines, $\mathrm{N}$-2-fluorenylacetamide and $3,3^{\prime}$-dichlorobenzidine, were incubated in varying amounts with RER to produce dose-response curves.

\section{Specificity of radiolabelling}

In early experiments checking the specificity of radiolabelling, RNA was determined (Fleck and Begg, 1954) to ascertain the correlation between RNA/protein ratios and the radiolabelling results. To test the specificity of RNA radiolabelling, the RNA was extracted as perchloric-acid-soluble hydrolysis products, free from contaminating DNA and protein (Fleck and Begg, 1954) and RNA in the samples was measured by the method of Fleck and Begg and the radioactivity measured as described previously.

To check that the ribosomes were uniformly radiolabelled, the RNA and radioactivity content of RER samples were estimated before and after treatment with $5 \mathrm{~mm}$ EDTA. According to Sabatini et al. (1966) this process removes most of the small ribosomal sub-units and some of the large sub-units. RER, at a concentration of $5 \mathrm{mg}$ protein $/ \mathrm{ml}$, was incubated in $0 \cdot 25 \mathrm{M}$ STKM buffer, $\mathrm{pH} 7 \cdot 5$, containing EDTA at a final concentration of $5 \mathrm{~mm}$ for $0.5 \mathrm{~h}$ at $25^{\circ} \mathrm{C}$ in a shaking water bath. The resultant suspension was layered over a discontinuous density gradient consisting of $10 \mathrm{ml}$ of $2 \cdot 0 \mathrm{M}$ STKM and $2.0 \mathrm{ml}$ of $1 \cdot 35 \mathrm{M}$ STKM and centrifuged at $105,000 \mathrm{~g}(\max )$ for $4.5 \mathrm{~h}$ at $4^{\circ} \mathrm{C}$. The $1.35 \mathrm{M}$ STKM layer containing the membranes was removed, diluted with $0 \cdot 25 \mathrm{M}$ STKM and centrifuged at $105,000 \mathrm{~g}(\max )$ for $1.5 \mathrm{~h}$ to yield a pellet of RER stripped of ribosomes. RNA and radioactivity and protein of this stripped membrane, and of the original RER membrane were analysed as previously described.

\section{RESULTS}

Some additional experiments were carried out to examine dose responses and the effects of metabolism.

\section{Specificity of radiolabelling}

Extraction of RNA from membranes and the determination of radioactivity in the extract showed that more than $90 \%$ of the label was associated with RNA in both RER and SER.

\section{TABLE IV.1.-Treatment of $R E R$ with EDTA to Produce Stripped RER}

\begin{tabular}{lcccc}
\multicolumn{1}{c}{$\begin{array}{c}\text { Membrane } \\
\text { type }\end{array}$} & $\begin{array}{c}\text { Protein } \\
\text { ratio }\end{array}$ & & Protein & RNA \\
RER & $0 \cdot 152$ & & 2034 & 13,390 \\
Stripped RER & $0 \cdot 073$ & & 969 & 13,269 \\
SER & 0.020 & & 381 & 19,106
\end{tabular}

Table IV.1 shows the results of treating RER with $5 \mathrm{~mm}$ EDTA. There is good agreement between the 2 methods used to estimate degranulation, a value of $59.8 \%$ being obtained from RNA/protein ratios, and one of $64.4 \%$ by specificactivity measurements. The specific-activity values for RNA in RER and stripped RER are also in good agreement, indicating that the ribosomal RNA is uniformly radiolabelled.

Table IV.2 shows a comparison between RNA/protein ratios and specific-activity measurements on the same membrane samples incubated with 2 carcinogens. This confirms the close correlation between the 2 methods.

Table IV.3 shows the individual results for all the compounds tested. Using radioactivity to detect degranulation, $\%$ degranulation $>5 \%$ was regarded as a positive result.

Figure IV.1 shows data obtained incubating varying amounts of 3,3'-dichlorobenzidine with RER aliquots. The data 


\section{TABLE IV.2.-Effect of Carcinogens on Degranulation as Measured by RNA/Protein Ratio and Specific Activity Estimation.}

RNA/protein ratio

$\%$ Degranulation

Specific activity (d/s/mg protein)

$\%$ Degranulation
Control

$$
\frac{0 \cdot 141}{1441 \cdot 0}
$$

\section{Compound}

Acridine

2-Acetylaminofluorene

4-Acetylaminofluorene

Aflatoxin $\mathbf{B}_{1}+$ generating system - generating system

4-Aminoazobenzene

2-Aminobiphenyl

4-Aminobiphenyl

2-Aminochrysene

6-Aminochrysene

3-Aminopyrene

2-Aminonaphthalene-1-sulphonic acid

Aniline

p-Anisidine

Anthracene

2-Aminoanthracene

Anthranilic acid

Anthraquinone

Anthrone

1,2-Benzanthracene

Benzanthrone

Benzidine

Benzimidazole

Benzoic acid

3,4-Benzpyrene

6-Benzoyl-2-naphthol

Biphenyl

Bis azo compound

Bis(Chloromethyl)ether

N,N'-Bis(2-naphthyl)-pphenylenediamine

Butanesultone

Caffeine

Calmagite

Camphor

Carbazole

Chlorambucil

Chloramine T

Cholesterol

Colchicine

Croton oil

Cyanocobalamin (B 12)

Cycasin acetate

Cyclohexylamine

Cyclophosphamide

3,3'-Diaminobenzidine

2,7-Diaminofluorene

3,4,5,6-Dibenzacridine

1,2,3,4-Dibenzanthracene

3,4,9,10-Dibenzpyrene

$3,3^{\prime}$-Dichlorobenzidine

2,4-Dichlorophenoxyaceate

Dicyclohexylamine

12

12

$8 \cdot 5$

$8 \cdot 5$

12

12

12

$8 \cdot 5$

12

12

12

$8 \cdot 5$

12

$8 \cdot 5$

12

12

12

12

$8 \cdot 5$

12

12

12

12

12

$8 \cdot 5$

$8 \cdot 5$

12

$8 \cdot 5$

12

12

12 $\begin{array}{cc}\text { Diethylnitrosamine } & 3,4 \text {-Benzpyrene } \\ 0 \cdot 128 & 0 \cdot 115 \\ 12 \cdot 8 & 24 \cdot 5 \\ 1332 \cdot 0 & 1164 \cdot 0 \\ 10 \cdot 3 & 26 \cdot 1\end{array}$

\begin{tabular}{|c|c|c|c|}
\hline \multirow{2}{*}{$\begin{array}{l}\text { Incubate } \\
(\mu \mathrm{g} / \mathrm{ml})\end{array}$} & \multirow{2}{*}{$\begin{array}{c}\text { Degranulation } \\
(\%)\end{array}$} & \multicolumn{2}{|c|}{ Carcinogenicity } \\
\hline & & in test & in lit \\
\hline 12 & $3 \cdot 5$ & - & - \\
\hline $8 \cdot 5$ & $14 \cdot 4$ & + & + \\
\hline $8 \cdot 5$ & $9 \cdot 6$ & + & - \\
\hline 12 & $1 \cdot 3$ & - & + \\
\hline 12 & $9 \cdot 6$ & + & + \\
\hline 12 & $25 \cdot 5$ & + & + \\
\hline 12 & $3 \cdot 3$ & - & - \\
\hline 12 & $18 \cdot 0$ & + & + \\
\hline 17 & $15 \cdot 8$ & + & + \\
\hline 17 & $18 \cdot 1$ & + & + \\
\hline $8 \cdot 5$ & $21 \cdot 3$ & + & + \\
\hline 12 & $2 \cdot 6$ & - & - \\
\hline
\end{tabular}

TABLe IV.3.

$2 \cdot 5$

$23 \cdot 5$

$14 \cdot 4$

$14 \cdot 5$

$>3 \cdot 7$

$4 \cdot 7$

$4 \cdot 0$

$12 \cdot 6$

$21 \cdot 3$

$21 \cdot 7$

$>2 \cdot 6$

$3 \cdot 5$

$15 \cdot 4$

$5 \cdot 4$

$3 \cdot 2$

$3 \cdot 9$

$>2 \cdot 0$

$7 \cdot 7$

$12 \cdot 3$

$4 \cdot 0$

$20 \cdot 2$

$3 \cdot 4$

$26 \cdot 9$

$3 \cdot 0$

$>2 \cdot 7$

$2 \cdot 3$ 
TABLE IV.3-continued.

D.D.T.

Compound

Dieldrin

Diethylnitrosamine

Diethylstilboestrol

3,3'-Dimethoxybenzidine

4-Dimethylaminoazobenzene

9,10-Dimethylanthracene

p-Dimethylaminobenzaldehyde

7,9-Dimethylbenzacridine

7,10-Dimethylbenzacridine

9,10-Dimethyl-1,2-benzanthracene

1,1'-Dimethyl-4,4' - bipyridinium dichloride

3,3'-Dimethylbenzidine

Dimethylcarbamoyl chloride

Dimethylformamide

Dimethylnitrosamine

2,3-Dimethylquinoxaline

Dinitrobenzene

2,4-Dinitrofluorobenzene

2,4-Dinitrophenol

Dinitrosopentamethylene tetramine

DL-Ethionine

1,1'-Ethylene-2,2' -bipyridinium dibromide

Ethylenethiourea

Ethyl methanesulphonate

Hexachlorocyclohexane

Hexamethylphosphoramide

Hydrazine

Hydrocortisone

Indole

Merchlorethamine

20-Methylcholanthrene

Methylene bis(2-chloroaniline)

2-Methylindole

MNNG

3-Methyl-4-nitroquinoline-N-oxide

Mitomycin $\mathrm{C}+$ generating system

Morgan's base - generating system

Naphthalene

1-Naphthol

2-Naphthol

1-Naphthylamine

2-Naphthylamine

2-Naphthylamine disulphonic acid

Nitrobenzene

2-Nitrobiphenyl

4-Nitrobiphenyl

2-Nitrofluorene

N-Nitrosodiphenylamine

N-Nitrosoephedrine

$\mathrm{N}$-Nitrosofolic acid

4-Nitroquinoline-N-oxide

4-Nonylphenol/ethylene oxide condensate

Orotic acid

Perylene

Phenobarbital

N-phenyl-2-naphthylamine

Propanesultone

$\beta$-Propiolactone

Resorcinol
Incubate

$(\mu \mathrm{g} / \mathrm{ml})$

12

12

17

12

12

12

12

12

12

12

$8 \cdot 5$

12

12

12

12

12

12

12

12

12

12

12

12

12

12

12

12

12

12

12

12

12

12

$8 \cdot 5$

12

12

12

12

12

12
Degranulation

(\%)

$>1 \cdot 5$

$4 \cdot 3$

$26 \cdot 4$

$3 \cdot 2$

$11 \cdot 6$

$14 \cdot 3$

$1 \cdot 3$

$>2 \cdot 0$

$19 \cdot 3$

$20 \cdot 1$

$13 \cdot 5$

$4 \cdot 1$

$10 \cdot 5$

$3 \cdot 5$

$>0 \cdot 3$

$12 \cdot 7$

$7 \cdot 1$

$0 \cdot 1$

$>6 \cdot 5$

$6 \cdot 8$

$3 \cdot 1$

$10 \cdot 2$

$1 \cdot 7$

$>7 \cdot 8$

$4 \cdot 1$

$12 \cdot 4$

$2 \cdot 8$

$>2 \cdot 4(\mathrm{c})$

$4 \cdot 0$

$>0 \cdot 8(\mathrm{c})$

$>2 \cdot 6(\mathrm{c})$

$19 \cdot 1$

$17 \cdot 9$

$8 \cdot 1$

$19 \cdot 0$

$>1 \cdot 6(\mathrm{c})$

$>0 \cdot 4$

$17 \cdot 4$

$3 \cdot 3$

$>0.8$

$>1 \cdot 3$

$1 \cdot 4$

$9 \cdot 9$

$16 \cdot 4$

$2 \cdot 2$

$4 \cdot 5$

$10 \cdot 5$

$11 \cdot 4$

$17 \cdot 1$

$>1 \cdot 8$

$9 \cdot 7$

$1 \cdot 1$

$8 \cdot 0$

$>3 \cdot 6$

$>5 \cdot 2$

$0 \cdot 0$

$>0 \cdot 6$

$6 \cdot 5$

$12 \cdot 0$

$17 \cdot 3$

$>0 \cdot 4$
Carcinogenicity

$\overbrace{\text { in test }}^{\text {in lit. }}$

$\begin{array}{ll}- & - \\ - & - \\ + & + \\ + & + \\ + & + \\ + & + \\ + & + \\ + & + \\ + & + \\ - & +\end{array}$

$+\quad+$

-

$+\quad+$

$+\quad-$

- $\quad \overline{+}$

$+\quad$

$+$

$+$

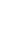

$+$ 


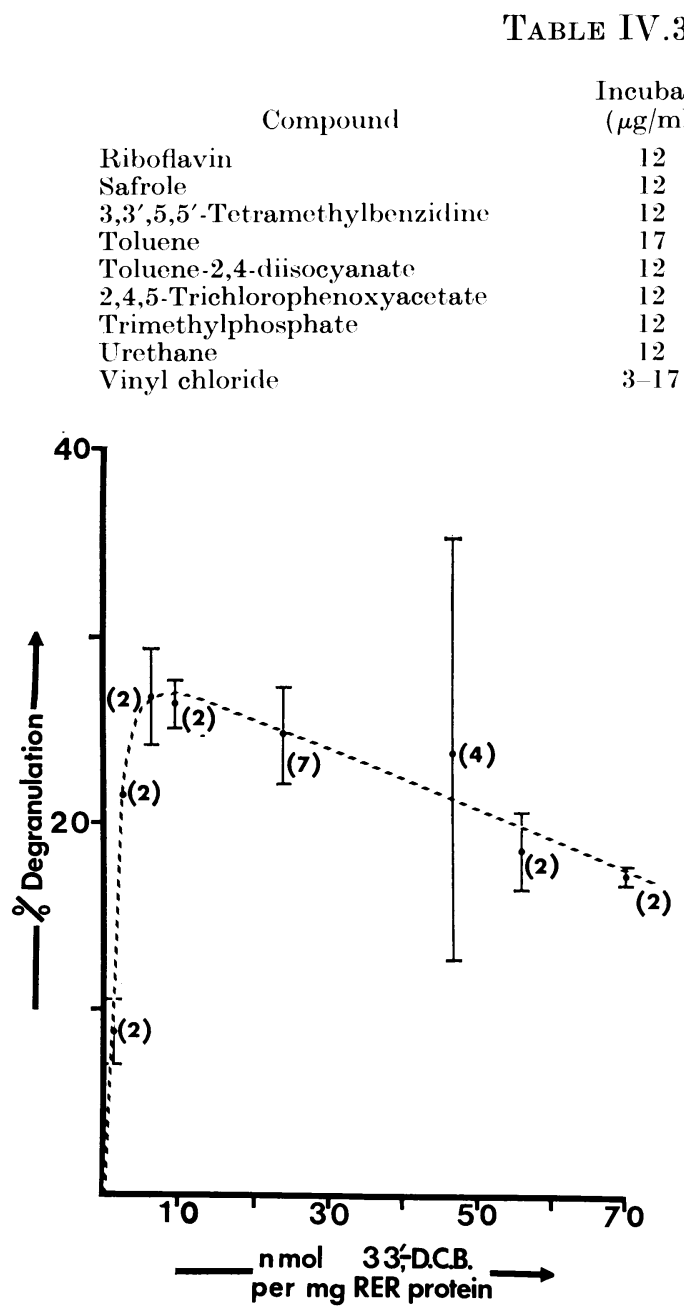

FIG. 1.-Effect of varying concentrations of $3,3^{\prime}$-dichlorobenzidine $\left(3,3^{\prime}\right.$ DCB) on the extent of degranulation of RER. The points are means of the number of determinations shown in parentheses; the bars indicate ranges.

are from several membrane samples, the concentration of compound being adjusted to take into account the amount of membrane protein present, and hence the amount of microsomal enzymes. Doseresponse experiments were also carried out on further compounds.

\section{DISCUSSION}

Experiments reported in the results confirm that RER membranes prepared

\section{continued.}

$\underset{(\%)}{\operatorname{Degranulation}}$

Carcinogenicity

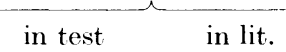

$$
>5 \cdot 6
$$

$16 \cdot 8$

$19 \cdot 3$

$>2 \cdot 7$

$0 \cdot 1$

$>5 \cdot 8$

$>3 \cdot 8$

$3 \cdot 8$

$>\mathrm{C}$

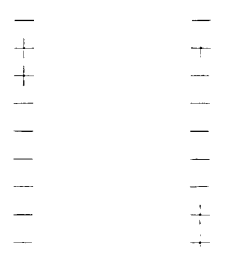

contain uniformly labelled RNA, and that $>90 \%$ of the radioactivity is associated with RNA. The results thus confirm that radioactivity can be equated with RNA content.

Of the 58 carcinogens tested, $41(71 \%)$ gave a positive result. A correct negative result was obtained with 44 of 62 noncarcinogens tested $(71 \%)$. The overall predictive value for all compounds was $71 \%$.

Aflatoxin $B_{1}$ and mitomycin $C$ both gave a positive result in the absence of NADPH, but a negative result in the presence of NADPH. The result with aflatoxin $\mathrm{B}_{1}$ confirms data obtained by Williams and Rabin (1971). However, evidence has been reported that aflatoxin $B_{1}$ must be metabolized to exert its carcinogenic effect (Garner, 1973), 2,3epoxyaflatoxin $B_{1}$ being proposed as the probable reactive compound and therefore a possible ultimate carcinogen (Garner, 1973; Swenson et al., 1973).

There appears to be no correlation between extent of degranulation and carcinogenic potency. For example, aflatoxin $B_{1}$, a potent liver carcinogen, causes less degranulation than 3-aminopyrene. Similarly, the test is not specific for liver carcinogens, compounds as diverse in action as some polycyclic hydrocarbons and 2-naphthylamine also giving positive results.

Some caution is needed when this work is compared with that of other laboratories. It is well known that microsomal activity against a variety of substrates shows wide variation between rats of different strains (Page and Vesell, 1969) and age (Shoemaker and Hamrick, 
1974). Differing conditions of husbandry, and the nutritional state of the animals also have effects on the cytochrome P450 levels and subsequently on the enzymic activity of microsomes (Vesell, 1967; Vesell et al., 1972; Basu and Dickerson, 1974). All these factors could, therefore, influence the metabolism of carcinogens.

Figure IV.1 illustrates a dose-response curve for $3,3^{\prime}$-DCB. Similar curves were obtained using other carcinogens. The data reflect the care needed in choosing dose levels in degranulation assays. Increasing the carcinogen concentration above a certain level decreases the degranulation. The concentrations used in the evaluation screen were those falling in the area of maximum degranulation.

\section{REFERENCES}

Basu, T. K. \& Dickerson, J. W. T. (1974) Interrelationships of Nutrition and the Metabolism of Drugs. Chem. Biol. Interact., 8, 193.

Borton, P., Carson, R. \& Reed, D. J. (1974) Stability of Rat Liver Microsomes Quick Frozen with Liquid Nitrogen and Stored at $-85^{\circ} \mathrm{C}$. Biochem. Pharmacol., 23, 2332.

Flaks, B. (1970) Changes in the Fine Structure of Rat Hepatocytes during the Early Phases of Chronic 2-acetylaminofluorene Intoxication. Chem. Biol. Interact., 2, 129.

Fleck, A. \& BegG, D. (1954) The Estimation of Ribonucleic Acid Using Ultraviolet Absorption Measurements. Biochem. biophys. Acta., 108, 333.

Fleischer, S. \& Kervina, M. (1974) Subcellular Fractionation of Rat Liver. Meth. Enzym., 31 (Part A), 6.

Garner, R. C. (1973) Chemical Evidence for the Formation of a Reactive Aflatoxin $\mathrm{B}_{1}$ Metabolite by Hamster Liver Microsomes. FEBS Letters, 36, 261.

Gaunce, A. P. \& D'Iorio, A. (1970) Microdetermination of Protein by an Automated Lowry Method. Anal. Biochem., 37, 204.

Ketterer, B., Holt, S. J. \& Ross-Mansell, P.
(1967) The Effect of a Single Intraperitoneal Dose of the Hepatocarcinogen 4-dimethylaminoazobenzene on the Rough Surfaced Endoplasmic Reticulum of the Liver of the Rat. Biochem. J., 103, 692.

Loeb, J. M., Howell, R. R. \& Tomkins, G. M. (1965) Turnover of Ribosomal RNA in Rat Liver. Science, 149, 1093.

Lowry, O. H., Rosebrough, N. J., Farr, A. L. \& Randall, R. J. (195l) Protein Measurement with the Folin Phenol Reagent. J. biol. Chem., 193, 265 .

Page, J. G. \& Vesell, E. S. (1969) Hepatic Drug Metabolism in Ten Strains of Norway Rat Before and After Pretreatment with Phenobarbital. Proc. Soc. exp. Biol. Med., 131, 256

Porter, K. R. \& BRuni, C. (1959) An Electron Microscope Study of the Early Effects of $3^{\prime}$-MeDAB on Rat Liver Cells. Cancer Res., 19, 997.

Purchase, I. F. H. \& Lefevre, P. A. (1975) Rapid Tests for Carcinogens. Chemy. Indy., 10, 415.

Sabatini, D. D., Tashiro, Y. \& Palade, G. E. (1966) On the Attachment of Ribosomes to Microsomal Membranes. J. mol. Biol., 19, 503.

Shommaker, D. D. \& Hamrick, M. E. (1974) Stoichiometry of Drug Metabolism in Maturing Male Rats. Biochem. Pharmacol., 23, 2325.

Svoboda, D. \& Higginson, J. (1968) A Comparison of Ultrastructural Changes in Rat Liver due to Chemical Carcinogens. Cancer Res., 28, 1703.

Swenson, D. H., Miller, J. A. \& Miller, E. C. (1973) 2,3-Dihydro-2,3-dihydroxyaflatoxin $B_{1}$ : an Acid Hydrolysis Product of an RNA Aflatoxin $B_{1}$ Adduct Formed by Hamster and Rat Liver Microsomes. Biochem. biophys. Res. Commun., 53, 1260.

VESELL, E. S. (1967) Induction of Drug Metabolising Enzymes in Liver Microsomes of Mice and Rats by Softwood Bedding. Science, 157, 1057.

Vessell, E. S., Lang, C. M., White, W. J., PassaNanTI, G. T. \& TripP, S. L. (1972) Hepatic Drug Metabolism in Rats: Impairment in a Dirty Environment. Science, 179, 896.

Williams, D. J. \& RaBIN, B. R. (1969) Disruption by Carcinogens of the Hormone Dependent Association of Membranes with Polysomes. Nature, 232, 102.

Williams, D. J. \& Rabin, B. R. (1969) The Effects of Aflatoxin $B_{1}$ and Steroid Hormones on Polysome Binding to Microsomal Membranes as Measured by the Activity of an Enzyme Catalysing Disulphide Interchange. FEBS Letters, 4, 103. 